\title{
EFFECT OF EXERCISE ON CARDIAC OUTPUT AND PULMONARY ARTERIAL PRESSURE IN NORMAL PERSONS AND IN PATIENTS WITH CARDIOVASCULAR DISEASE AND PULMONARY EMPHYSEMA ${ }^{1}$
}

\author{
By JOHN B. HICKAM ${ }^{2}$ aNd WALTER H. CARGILL \\ (From the Departments of Medicine, Emory University, Atlanta, Ga., and \\ Duke University, Durham, N.C.)
}

(Received for publication July 21, 1947)

The changes in the circulation of patients with heart disease and with emphysema have been studied many times when the patient was at bed rest. There is little information as to the changes produced when the circulatory requirements exceed the resting level. This information is probably of more importance than resting measurements as the greater part of existence is one of activity. Chronic emphysema produces changes in the heart in many patients. Congestive failure leads to water logging of the lungs. It was felt that simultaneous measurements of the cardiac output and pulmonary arterial pressure in normal persons and in those with emphysema and heart failure would aid in the understanding of the alterations of cardiac and pulmonary functions occurring in these diseases. The purpose of this paper is to present these data and to discuss their significance.

\section{METHODS}

Intracardiac catheterization was performed in the usual manner (1). The catheter was passed for a distance of 1 to 2 inches into the right or left main branch of the pulmonary artery. Pulmonary arterial pressures were recorded by a Hamilton manometer and mean pressures determined by planimetric integration, covering a period of at least 2 respiratory cycles. Atrial pressures were determined either in the same fashion, using a sufficiently sensitive Hamilton manometer, or by the use of a saline manometer. Systemic arterial pressures were measured in most cases from the brachial artery, using a Hamilton manometer. The point of zero reference was $5 \mathrm{~cm}$. beneath the fourth left costochondral junction. Mixed venous blood samples were taken from the pulmonary artery in nearly all cases; otherwise, they were from the ventricle or atrium. Arterial samples were taken through an in-lying needle, usually in the brachial artery but occasionally in the radial or femoral arteries. Blood was col-

\footnotetext{
1 This work was supported by a grant from the Life Insurance Medical Research Fund.

2 Holder of American College of Physicians Clinical Fellowship, 1946-1947.
}

lected under oil, stored in ice, and analyzed for oxygen as rapidly as possible, using the manometric method of Van Slyke and Neill. Analyses were performed in duplicate and required to check within 0.1 vol. per cent. For the determination of oxygen consumption, 2- or 3-minute samples of expired air were collected in Douglas bags, analyzed in a Haldane apparatus, and measured in a Tissot spirometer. Exercise was carried out in the supine position by causing the patients to push with their feet against weighted pedals. The stroke distance was 12 inches. Both pedals were usually pushed together, and the total resistance could be fixed at 11,30 , or $42 \mathrm{lbs}$. The actual work rate in foot pounds per minute is of value only in indicating the general order of magnitude of the work done. The patients were not trained in this type of exercise and consequently showed obvious differences in economy of effort. The work rate was adjusted to the ability of the patient but was kept as steady as possible. Determination of the cardiac output was not begun until after at least 3 minutes of steady exercise. For the control measurements preceding exercise, no attempt was made to bring the subjects to a truly basal condition. They were, however, usually in the postabsorptive state or at most had had only a very light breakfast and had been at rest for at least 30 minutes before observations were begun. All measurements were made at 1 sitting, except in Case 24, where several days elapsed between determinations at rest and those during exercise.

\section{RESULTS}

The pertinent data on 28 subjects are presented in Table $I$ and graphically interpreted in Figures 1 to 8 .

\section{Normal subjects}

Eight persons were studied who were believed to have normal cardiovascular systems. Cases 1 to 5 had latent or asymptomatic CNS syphilis; Case 6 had a probable duodenal ulcer; and Cases 7 and 8 were convalescent, respectively, from hepatitis and pneumococcal pneumonia. The resting oxygen consumption of the group as a whole was some- 
TABLE I

\begin{tabular}{|c|c|c|c|c|c|c|c|c|c|c|c|c|c|c|}
\hline \multirow{3}{*}{ No. } & \multirow{2}{*}{ Case } & \multirow{2}{*}{ Age } & \multirow{2}{*}{ Diagnosis } & \multirow{2}{*}{$\begin{array}{l}\text { Work } \\
\text { rate }\end{array}$} & \multirow{2}{*}{$\begin{array}{l}\text { Surf. } \\
\text { area }\end{array}$} & \multirow{2}{*}{$\begin{array}{l}\text { Atrial } \\
\text { press. }\end{array}$} & \multirow{2}{*}{$\begin{array}{c}\text { Mean } \\
\text { pulm. } \\
\text { art. } \\
\text { press. }\end{array}$} & $\begin{array}{l}\text { Systemic } \\
\text { art. press. }\end{array}$ & \multicolumn{3}{|c|}{ Blood oxygen } & \multirow{2}{*}{$\begin{array}{l}\text { A-V } \\
\text { diff. }\end{array}$} & \multirow{2}{*}{$\begin{array}{c}\text { Oxygen } \\
\text { consump. }\end{array}$} & \multirow{2}{*}{$\begin{array}{c}\text { Cardiac } \\
\text { index }\end{array}$} \\
\hline & & & & & & & & Sys. Dias. & Art. & Ven. & Sat. & & & \\
\hline & & & & $\begin{array}{l}f t . l b . / \\
\text { min. }\end{array}$ & $s q . m$. & mm. $H_{8}$ & $m m . H_{8}$ & $m m \cdot H_{g}$ & \multicolumn{4}{|c|}{ oolumes per cent } & cc./min./M.2 & L./min./M.2 \\
\hline
\end{tabular}

Normal

\begin{tabular}{|c|c|c|c|c|c|c|c|c|c|c|c|c|c|c|c|}
\hline 1 & W. H. & 15 & Latent syphilis & $\begin{array}{r}0 \\
760\end{array}$ & 1.50 & $\begin{array}{l}4 \\
5\end{array}$ & $\begin{array}{l}12 \\
14\end{array}$ & $\begin{array}{r}95 \\
119\end{array}$ & $\begin{array}{l}53 \\
67\end{array}$ & \begin{tabular}{|l|}
16.5 \\
17.3
\end{tabular} & $\begin{array}{l}13.4 \\
11.5\end{array}$ & 17.5 & $\begin{array}{l}3.1 \\
5.8\end{array}$ & $\begin{array}{l}177 \\
387\end{array}$ & $\begin{array}{l}5.7 \\
6.7\end{array}$ \\
\hline 2 & V.W. & 35 & $\begin{array}{l}\text { Asymptomatic CNS } \\
\text { syphilis }\end{array}$ & $\begin{array}{r}0 \\
760\end{array}$ & 1.85 & $\begin{array}{l}0 \\
1\end{array}$ & $\begin{array}{r}8 \\
13\end{array}$ & 118 & 70 & \begin{tabular}{|}
16.0 \\
15.9
\end{tabular} & $\begin{array}{l}11.6 \\
10.6\end{array}$ & 16.9 & $\begin{array}{l}4.4 \\
5.3\end{array}$ & $\begin{array}{l}162 \\
342\end{array}$ & $\begin{array}{l}3.7 \\
6.5\end{array}$ \\
\hline 3 & R. R. & 20 & $\begin{array}{l}\text { Asymptomatic CNS } \\
\text { syphilis }\end{array}$ & $\begin{array}{r}0 \\
1170\end{array}$ & 1.71 & 0 & $\begin{array}{l}15 \\
14\end{array}$ & $\begin{array}{l}118 \\
130\end{array}$ & $\begin{array}{l}64 \\
74\end{array}$ & $\begin{array}{l}15.7 \\
15.6\end{array}$ & $\begin{array}{l}11.3 \\
10.2\end{array}$ & 16.2 & $\begin{array}{l}4.4 \\
5.4\end{array}$ & $\begin{array}{l}115 \\
263\end{array}$ & $\begin{array}{l}2.6 \\
4.9\end{array}$ \\
\hline 4 & G. D. & 30 & $\begin{array}{l}\text { Asymptomatic CNS } \\
\text { syphilis }\end{array}$ & $\begin{array}{r}0 \\
920\end{array}$ & 1.84 & & $\begin{array}{l}12 \\
14\end{array}$ & $\begin{array}{l}140 \\
110\end{array}$ & $\begin{array}{l}88 \\
80\end{array}$ & $\begin{array}{l}17.1 \\
17.6\end{array}$ & $\begin{array}{l}14.3 \\
11.5\end{array}$ & 17.7 & $\begin{array}{l}2.8 \\
6.1\end{array}$ & $\begin{array}{l}141 \\
314\end{array}$ & $\begin{array}{l}4.9 \\
5.2\end{array}$ \\
\hline 5 & R. H. & 27 & $\begin{array}{l}\text { Asymptomatic CNS } \\
\text { syphilis }\end{array}$ & $\begin{array}{r}0 \\
1430\end{array}$ & 1.86 & $\mathbf{0}$ & $\begin{array}{r}8 \\
10\end{array}$ & $\begin{array}{l}116 \\
150\end{array}$ & $\begin{array}{l}65 \\
92\end{array}$ & $\begin{array}{l}19.9 \\
19.9\end{array}$ & $\begin{array}{l}16.1 \\
15.8\end{array}$ & 20.2 & $\begin{array}{l}3.8 \\
4.1\end{array}$ & $\begin{array}{l}177 \\
398\end{array}$ & $\begin{array}{l}4.7 \\
9.7\end{array}$ \\
\hline 6 & H. A. & 23 & Duodenal ulcer & 0 & 1.68 & & $\begin{array}{l}14 \\
12\end{array}$ & $\begin{array}{l}134 \\
127\end{array}$ & $\begin{array}{l}65 \\
71\end{array}$ & $\begin{array}{l}18.7 \\
18.7\end{array}$ & $\begin{array}{l}14.8 \\
14.5\end{array}$ & 19.4 & $\begin{array}{l}3.9 \\
4.2\end{array}$ & $\begin{array}{l}193 \\
254\end{array}$ & $\begin{array}{l}5.0 \\
6.0\end{array}$ \\
\hline 7 & W. W. & 15 & $\begin{array}{l}\text { Convalescent } \\
\text { hepatitis }\end{array}$ & $\begin{array}{r}0 \\
590\end{array}$ & 1.58 & $\begin{array}{l}\mathbf{0} \\
\mathbf{0}\end{array}$ & $\begin{array}{l}11 \\
13\end{array}$ & $\begin{array}{l}105 \\
114\end{array}$ & $\begin{array}{l}74 \\
79\end{array}$ & $\begin{array}{l}16.1 \\
16.1\end{array}$ & $\begin{array}{l}11.8 \\
11.1\end{array}$ & 16.8 & $\begin{array}{l}4.3 \\
5.0\end{array}$ & $\begin{array}{l}168 \\
280\end{array}$ & $\begin{array}{l}3.9 \\
5.5\end{array}$ \\
\hline 8 & E. C. & 21 & $\begin{array}{l}\text { Convalescent } \\
\text { pneumonia }\end{array}$ & $\begin{array}{r}0 \\
670\end{array}$ & 1.54 & 1 & 9 & 112 & 72 & $\begin{array}{l}14.9 \\
14.9\end{array}$ & $\begin{array}{r}10.9 \\
8.2\end{array}$ & 15.7 & $\begin{array}{l}4.0 \\
6.7\end{array}$ & $\begin{array}{l}126 \\
285\end{array}$ & $\begin{array}{l}3.1 \\
4.2\end{array}$ \\
\hline
\end{tabular}

Congestive failure

\begin{tabular}{|c|c|c|c|c|c|c|c|c|c|c|c|c|c|c|c|}
\hline 9 & D. M. & 64 & $\begin{array}{l}\text { Hypertension, } \\
\text { emphysema }\end{array}$ & $\begin{array}{r}0 \\
180\end{array}$ & 1.77 & 6 & $\begin{array}{l}46 \\
63\end{array}$ & $\mid$ & 106 & $\begin{array}{l}16.0 \\
15.9\end{array}$ & $\begin{array}{l}9.6 \\
6.4\end{array}$ & 20.7 & $\begin{array}{l}6.4 \\
9.5\end{array}$ & $\begin{array}{l}183 \\
231\end{array}$ & $\begin{array}{l}2.8 \\
2.4\end{array}$ \\
\hline 10 & T. T. & 40 & Hypertension & $\begin{array}{r}0 \\
170\end{array}$ & 1.64 & & $\begin{array}{l}34 \\
\mathbf{4 7}\end{array}$ & 206 & 141 & $\begin{array}{l}16.5 \\
16.5\end{array}$ & $\begin{array}{r}12.2 \\
7.4\end{array}$ & 17.4 & $\begin{array}{l}4.3 \\
9.1\end{array}$ & $\begin{array}{l}157 \\
205\end{array}$ & $\begin{array}{l}3.6 \\
2.3\end{array}$ \\
\hline 11 & J. G. & 63 & Hypertension & $\begin{array}{r}0 \\
220\end{array}$ & 1.54 & & $\begin{array}{l}15 \\
44\end{array}$ & 146 & 92 & $\begin{array}{l}17.5 \\
18.3\end{array}$ & $\begin{array}{r}11.1 \\
8.7\end{array}$ & 19.4 & $\begin{array}{l}6.4 \\
9.6\end{array}$ & $\begin{array}{l}167 \\
251\end{array}$ & $\begin{array}{l}2.6 \\
2.6\end{array}$ \\
\hline 12 & M. M. & 47 & $\begin{array}{l}\text { Hypertension, } \\
\text { pericard. effusion }\end{array}$ & $\begin{array}{r}0 \\
500\end{array}$ & 1.50 & 4 & $\begin{array}{l}42 \\
62\end{array}$ & $\begin{array}{l}127 \\
171\end{array}$ & $\begin{array}{l}108 \\
127\end{array}$ & $\begin{array}{l}18.0 \\
17.8\end{array}$ & $\begin{array}{r}10.8 \\
7.3\end{array}$ & 19.1 & $\begin{array}{r}7.2 \\
10.5\end{array}$ & $\begin{array}{l}150 \\
252\end{array}$ & $\begin{array}{l}2.1 \\
2.4\end{array}$ \\
\hline 13 & N. R. & 47 & Hypertension & $\begin{array}{r}0 \\
300\end{array}$ & 2.10 & $\begin{array}{l}8 \\
7\end{array}$ & $\begin{array}{l}40 \\
41\end{array}$ & 207 & 95 & $\begin{array}{l}13.5 \\
13.5\end{array}$ & $\begin{array}{l}9.0 \\
8.4\end{array}$ & 16.2 & $\begin{array}{l}4.5 \\
5.1\end{array}$ & $\begin{array}{l}164 \\
220\end{array}$ & $\begin{array}{l}3.7 \\
4.3\end{array}$ \\
\hline 14 & L. E. & 41 & $\begin{array}{l}\text { Syphilitic A. I., } \\
\text { hypertension }\end{array}$ & $\begin{array}{r}0 \\
220\end{array}$ & 1.71 & & $\begin{array}{l}18 \\
29\end{array}$ & 220 & 57 & $\begin{array}{l}14.2 \\
13.4\end{array}$ & $\begin{array}{l}8.3 \\
6.2\end{array}$ & 14.8 & $\begin{array}{l}5.9 \\
7.2\end{array}$ & $\begin{array}{l}190 \\
194\end{array}$ & $\begin{array}{l}3.2 \\
2.7\end{array}$ \\
\hline 15 & H. S. & 37 & Syphilitic A. I. & $\begin{array}{r}0 \\
180\end{array}$ & 1.70 & 7 & $\begin{array}{l}40 \\
57\end{array}$ & $\begin{array}{l}150 \\
150\end{array}$ & $\begin{array}{r}80 \\
100\end{array}$ & $\begin{array}{l}17.0 \\
17.0\end{array}$ & $\begin{array}{l}9.1 \\
7.4\end{array}$ & 20.7 & $\begin{array}{l}7.9 \\
9.6\end{array}$ & $\begin{array}{l}216 \\
186\end{array}$ & $\begin{array}{l}2.8 \\
1.9\end{array}$ \\
\hline $15 \mathrm{~A}$ & & & . & $\begin{array}{r}0 \\
330\end{array}$ & & & $\begin{array}{l}27 \\
39\end{array}$ & & & $\begin{array}{l}17.9 \\
18.2\end{array}$ & $\begin{array}{l}11.7 \\
11.2\end{array}$ & & $\begin{array}{l}6.2 \\
7.0\end{array}$ & $\begin{array}{l}125 \\
208\end{array}$ & $\begin{array}{l}2.1 \\
3.0\end{array}$ \\
\hline 16 & G.S. & 47 & Syphilitic A. I. & $\begin{array}{r}0 \\
500\end{array}$ & 1.73 & $\begin{array}{r}-2 \\
5\end{array}$ & $\begin{array}{l}25 \\
54\end{array}$ & $\begin{array}{l}149 \\
193\end{array}$ & $\begin{array}{l}55 \\
62\end{array}$ & $\begin{array}{l}14.1 \\
14.0\end{array}$ & $\begin{array}{l}7.4 \\
7.0\end{array}$ & 15.1 & $\begin{array}{l}6.7 \\
7.0\end{array}$ & $\begin{array}{l}120 \\
210\end{array}$ & $\begin{array}{l}2.2 \\
3.0\end{array}$ \\
\hline
\end{tabular}

what above the normal basal level. In Cases 1 and 4 the resting $\mathrm{A}-\mathrm{V}$ difference was small in proportion to the oxygen consumption. This was believed to be a result of anxiety. During exercise the oxy- gen consumption ranged between 250 and $400 \mathrm{cc}$. per square meter of body surface per minute. For comparison with more familiar types of activity, it may be noted that Douglas et al. (2) found that 
TABLE I-Continued

\begin{tabular}{|c|c|c|c|c|c|c|c|c|c|c|c|c|c|c|c|}
\hline \multirow{2}{*}{ No. } & \multirow{2}{*}{ Case } & \multirow{2}{*}{ Age } & \multirow{2}{*}{ Diagnosis } & \multirow{2}{*}{$\begin{array}{c}\text { Work } \\
\text { rate }\end{array}$} & \multirow{2}{*}{$\begin{array}{l}\text { Surf. } \\
\text { area }\end{array}$} & \multirow{2}{*}{$\begin{array}{l}\text { Atrial } \\
\text { press. }\end{array}$} & \multirow{2}{*}{$\begin{array}{l}\text { Mean } \\
\text { pulm. } \\
\text { art. } \\
\text { press. }\end{array}$} & \multicolumn{2}{|c|}{$\begin{array}{l}\text { Systemic } \\
\text { art. press. }\end{array}$} & \multicolumn{3}{|c|}{ Blood oxygen } & \multirow{2}{*}{$\begin{array}{l}\text { A-v } \\
\text { diff. }\end{array}$} & \multirow{2}{*}{$\begin{array}{l}\text { Oxygen } \\
\text { consump. }\end{array}$} & \multirow{2}{*}{$\begin{array}{l}\text { Cardiac } \\
\text { index }\end{array}$} \\
\hline & & & & & & & & Sys. $\mathrm{I}$ & Dias. & Art. & Ven. $\mid$ & Sat. & & & \\
\hline & & & & ft.lb./ & sq. $m$. & $m m . B g$ & $m m . H g$ & \multicolumn{2}{|c|}{$m m . H_{g}$} & \multicolumn{4}{|c|}{ rolumes per cent } & cc./min./M.2 & L./min./M.2 \\
\hline \multicolumn{16}{|c|}{ Mitral stenosis } \\
\hline 17 & W. N. & 16 & M.S., A.I. & $\begin{array}{r}0 \\
1500\end{array}$ & 1.92 & & $\begin{array}{l}\text { 45(VP) } \\
55(\mathrm{VP})\end{array}$ & $\begin{array}{l}150 \\
159\end{array} \mid$ & $\begin{array}{l}67 \\
79\end{array}$ & $\begin{array}{l}17.3 \\
17.7\end{array}$ & $\left|\begin{array}{l}13.6 \\
12.8\end{array}\right|$ & 18.3 & $\begin{array}{l}3.7 \\
4.9\end{array}$ & $\begin{array}{l}195 \\
366\end{array}$ & $\begin{array}{l}5.2 \\
7.6\end{array}$ \\
\hline 18 & H. W. & 41 & M.S. & $\begin{array}{r}0 \\
840\end{array}$ & 2.01 & $\begin{array}{r}4 \\
12\end{array}$ & $\begin{array}{l}33 \\
71\end{array}$ & $\begin{array}{l}108 \\
127\end{array}$ & $\begin{array}{l}58 \\
73\end{array}$ & $\begin{array}{l}14.6 \\
14.8\end{array}$ & $\begin{array}{r}10.6 \\
8.5\end{array}$ & 15.6 & $\begin{array}{l}4.0 \\
6.3\end{array}$ & $\begin{array}{l}163 \\
280\end{array}$ & $\begin{array}{l}4.2 \\
4.5\end{array}$ \\
\hline 19 & P. C. & 36 & M.S., A.F. & $\begin{array}{r}0 \\
840\end{array}$ & 2.11 & $\begin{array}{l}0 \\
1\end{array}$ & $\begin{array}{l}23 \\
41\end{array}$ & & & $\begin{array}{l}19.6 \\
20.0\end{array}$ & \begin{tabular}{|l|}
14.8 \\
11.8
\end{tabular} & 20.4 & $\begin{array}{l}4.8 \\
8.2\end{array}$ & $\begin{array}{l}158 \\
341\end{array}$ & $\begin{array}{l}3.3 \\
4.2\end{array}$ \\
\hline 20 & M. J. & 32 & M.S., M.I. & $\begin{array}{r}0 \\
920\end{array}$ & 1.69 & $\begin{array}{l}1 \\
2\end{array}$ & $\begin{array}{l}19 \\
22\end{array}$ & 109 & 53 & $\begin{array}{l}15.8 \\
16.9\end{array}$ & $\begin{array}{l}11.4 \\
10.2\end{array}$ & 16.9 & $\begin{array}{l}4.4 \\
6.7\end{array}$ & $\begin{array}{l}138 \\
291\end{array}$ & $\begin{array}{l}3.1 \\
4.3\end{array}$ \\
\hline 21 & L. H. & 21 & M.S., M.I. & 0 & 1.50 & & $\begin{array}{l}20 \\
22\end{array}$ & 110 & 70 & $\begin{array}{l}17.2 \\
17.5\end{array}$ & $\left|\begin{array}{r}11.3 \\
8.0\end{array}\right|$ & 17.6 & $\begin{array}{l}5.9 \\
9.5\end{array}$ & $\begin{array}{l}143 \\
275\end{array}$ & $\begin{array}{l}2.4 \\
2.9\end{array}$ \\
\hline 22 & A. W. & 36 & M.S., M.I., A.F. & $\begin{array}{r}0 \\
600\end{array}$ & 1.61 & ${ }_{11}^{7}$ & & & & $\begin{array}{l}17.6 \\
18.0\end{array}$ & \begin{tabular}{|l|}
12.6 \\
10.0
\end{tabular} & 19.5 & $\begin{array}{l}5.0 \\
8.0\end{array}$ & $\begin{array}{l}169 \\
278\end{array}$ & $\begin{array}{l}3.4 \\
3.4\end{array}$ \\
\hline 23 & L. B. & 52 & $\begin{array}{l}\text { Hypertension, } \\
\text { M.S., M.I., A.F. }\end{array}$ & 0 & 1.55 & $\begin{array}{l}4 \\
9\end{array}$ & $37(V P)$ & 184 & 68 & $\begin{array}{l}17.1 \\
18.2\end{array}$ & $\begin{array}{r}10.5 \\
5.9\end{array}$ & 18.3 & $\begin{array}{r}6.6 \\
12.3\end{array}$ & $\begin{array}{l}163 \\
358\end{array}$ & $\begin{array}{l}2.5 \\
2.9\end{array}$ \\
\hline
\end{tabular}

Pulmonary emphysema

\begin{tabular}{|c|c|c|c|c|c|c|c|c|c|c|c|c|c|c|c|}
\hline 24 & H. R. & 48 & $\begin{array}{c}\text { Emphysema, } \\
\text { hypertension }\end{array}$ & 0 & 1.55 & 0 & $\begin{array}{l}49(\mathrm{VP}) \\
78(\mathrm{VP})\end{array}$ & 195 & 130 & $\left|\begin{array}{l}18.1 \\
17.3\end{array}\right|$ & \begin{tabular}{|l|}
12.9 \\
12.3
\end{tabular} \mid & $20.5 \mid$ & $\begin{array}{l}5.2 \\
5.0\end{array}$ & $\begin{array}{l}196 \\
268\end{array}$ & $\begin{array}{l}3.8 \\
5.4\end{array}$ \\
\hline 25 & B. L. & 38 & Emphysema & $\begin{array}{r}0 \\
1000\end{array}$ & 1.73 & $\begin{array}{l}5 \\
6\end{array}$ & $\begin{array}{l}13 \\
22\end{array}$ & $\begin{array}{l}117 \\
146\end{array}$ & $\begin{array}{l}69 \\
85\end{array}$ & $\left|\begin{array}{l}17.8 \\
18.6\end{array}\right|$ & $\begin{array}{l}13.7 \\
11.8\end{array} \mid$ & 19.0 & $\begin{array}{l}4.1 \\
6.8\end{array}$ & $\begin{array}{l}173 \\
445\end{array}$ & $\begin{array}{l}4.2 \\
6.5\end{array}$ \\
\hline 26 & J. Y. & 62 & Emphysema & $\begin{array}{r}0 \\
480\end{array}$ & 1.54 & $\begin{array}{l}0 \\
7.0\end{array}$ & $\begin{array}{l}17 \\
24\end{array}$ & 121 & 54 & $\begin{array}{l}14.5 \\
14.5\end{array}$ & $\begin{array}{r}10.5 \\
8.8\end{array}$ & 15.8 & $\begin{array}{l}4.0 \\
5.7\end{array}$ & $\begin{array}{l}134 \\
251\end{array}$ & $\begin{array}{l}3.4 \\
4.4\end{array}$ \\
\hline 27 & C. $\mathrm{H}$. & 47 & Emphysema & $\begin{array}{r}0 \\
180\end{array}$ & 1.60 & 6 & $\begin{array}{l}24 \\
28\end{array}$ & $\begin{array}{l}114 \\
131\end{array}$ & $\begin{array}{l}74 \\
82\end{array}$ & $\begin{array}{l}16.3 \\
16.3\end{array}$ & $\begin{array}{r}10.8 \\
9.8\end{array}$ & 18.2 & $\begin{array}{l}5.5 \\
6.5\end{array}$ & $\begin{array}{l}184 \\
275\end{array}$ & $\begin{array}{l}3.4 \\
4.3\end{array}$ \\
\hline 28 & J. A. & 59 & $\begin{array}{c}\text { Emphysema, } \\
\text { hypertension }\end{array}$ & $\begin{array}{r}0 \\
55\end{array}$ & 1.50 & $\begin{array}{l}1 \\
4\end{array}$ & $\begin{array}{l}18 \\
24\end{array}$ & 170 & 100 & $\begin{array}{l}15.8 \\
15.7\end{array}$ & $\left|\begin{array}{l}12.5 \\
11.0\end{array}\right|$ & 18.7 & $\begin{array}{l}3.3 \\
4.7\end{array}$ & $\begin{array}{l}149 \\
200\end{array}$ & $\begin{array}{l}4.5 \\
4.2\end{array}$ \\
\hline
\end{tabular}

the basal oxygen consumption was increased by a factor of 1.4 on standing erect; by 2.7 on walking at $2 \mathrm{~m}$.p.h.; and by 3.8 on walking at $3 \mathrm{~m}$.p.h. The rate of exercise in these subjects, in terms of oxygen consumption, would therefore correspond to a very slow walk on a level floor. In Figure 1 the A-V oxygen difference for each subject at rest and exercise is plotted against the oxygen consumption, the 2 points for each subject being connected by a line for purposes of identification. In order to define more completely the normal range, the extent of these values in 19 normal basal subjects observed by Stead, Warren, Merrill, and Brannon (1) is indicated on the Figure by a rectangle.
For comparison with other groups in the present study, all points, with the exception of resting values in the 2 anxious individuals, are inclosed between straight lines. The area between these lines is considered to comprise the normal range of A-V oxygen difference' for the rates of oxygen consumption obtained with this type of exercise. The increased oxygen intake during exercise was achieved in part by a rise in the cardiac output and in part by an increase in the $\mathrm{A}-\mathrm{V}$ difference. In 5 subjects, the rise in cardiac output was the more important factor. In the 2 anxious persons, whose A-V differences at rest were abnormally low, and in Case 8, the patient convalescent from pneu- 


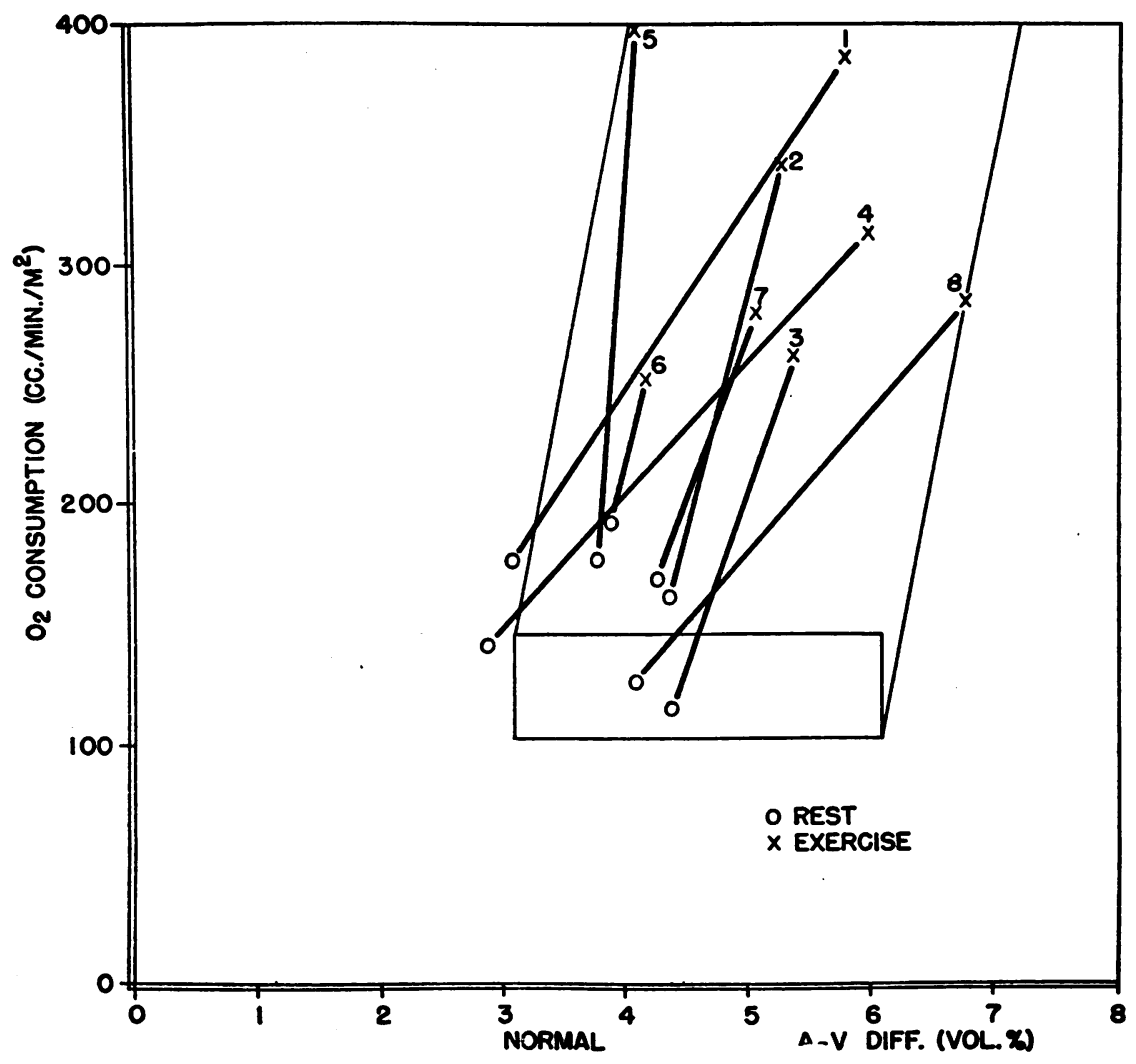

Fig. 1. Effect of Exercise on Oxygen Consumption and Arteriovenous Oxygen Difference in Normal Subjects

Numerals on this and succeeding charts correspond to subject numbers in Table I. Rectangle indicates range of values in normal basal subjects studied by Stead et al. (1). Region inclosed between straight lines from extremities of rectangle comprises apparent normal range of $\mathrm{A}-\mathrm{V}$ difference for indicated rates of oxygen consumption induced by exercise.

monia, an increase in the $\mathrm{A}-\mathrm{V}$ difference accounted for the major part of the increase in oxygen consumption on exercise. In general, during mild exercise in these subjects the $\mathrm{A}-\mathrm{V}$ oxygen difference was defended against rising to large values by an increase in the cardiac output. In this group, the $\mathrm{A}-\mathrm{V}$ difference did not exceed 6 vol. per cent except in Case 8, where it reached the value of 6.8 vol. per cent at a relatively low rate of oxygen consumption.

In Figure 2, the mean pulmonary arterial pressures in the normal group are plotted against cardiac index, the values for rest and exercise in each subject being connected by a straight line. Although the cardiac index extended over a range of 2.6 to 9.7 in different subjects, the mean pul- monary pressures remained within the limits of 8 to $15 \mathrm{~mm}$. $\mathrm{Hg}$.

\section{Congestive failure}

Eight patients were studied who had congestive heart failure on the basis of either systemic hypertension or syphilitic aortic insufficiency. The degree of failure was, or had recently been, so severe as to compel complete bed rest. Patients Nos. 9 to 13 had hypertension, complicated in No. 9 by pulmonary emphysema and in No. 12 by pericardial effusion of undetermined cause. Patient No. 14 had hypertension and syphilitic aortic insufficiency. Patients Nos. 15 and 16 had syphilitic aortic insufficiency. Patient No. 15 was studied on 2 occasions, once while in severe failure and 


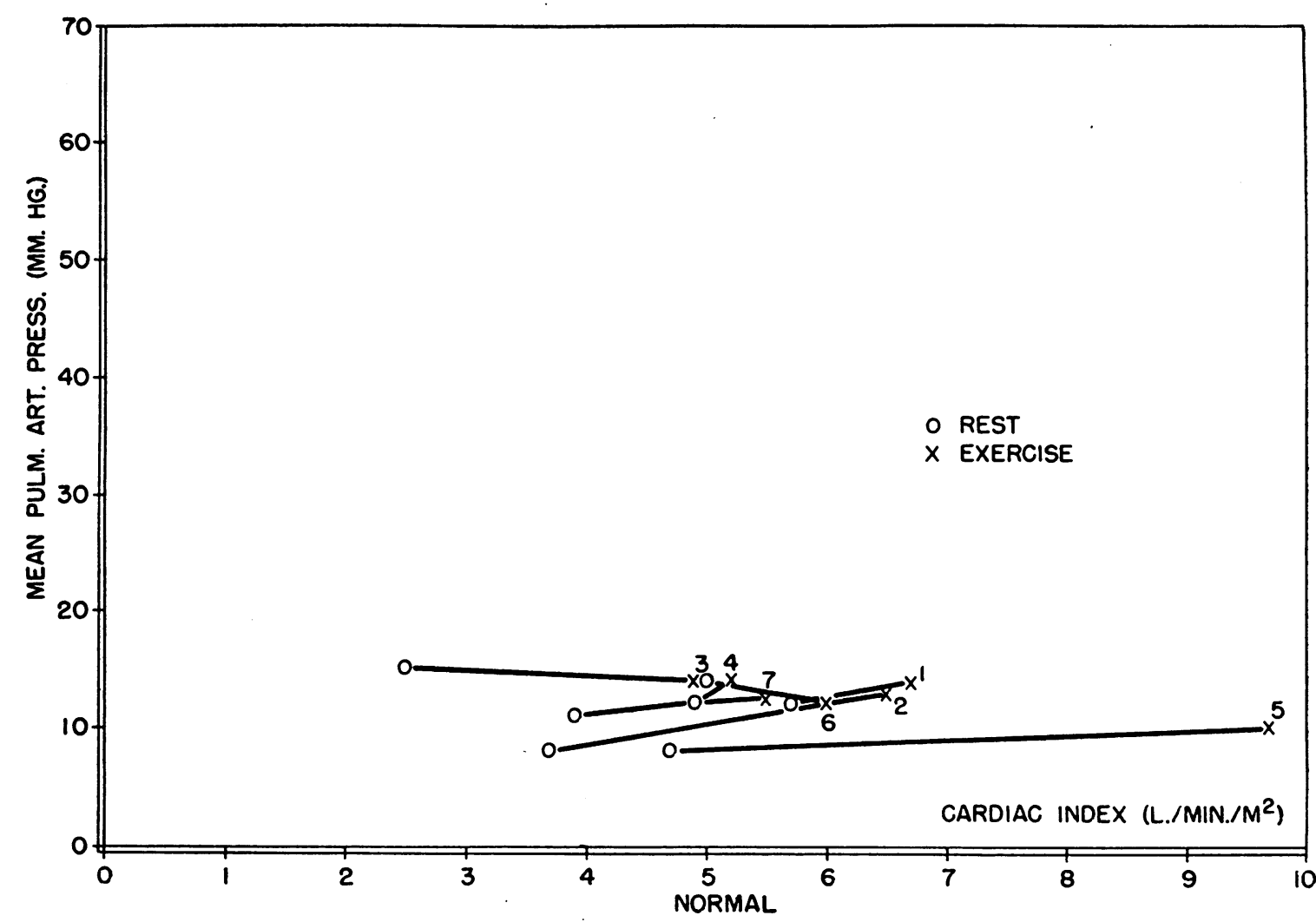

Fig. 2. Effect of Exercise on Mean Pulmon ary Artertal Pressure and Cardiac Index in Normal Subjects

again 10 days later $(15 \mathrm{~A})$, when he was clinically much improved. Cases $13,15 \mathrm{~A}$ and 16 had improved to the point of being comfortable while lying flat, while the others still had moderate orthopnea.

The ability of these patients to carry on sustained work was severely limited by weakness and dyspnea. They were encouraged to do as well as possible, and the work rate attained was regarded by most of them as a considerable effort for the 8 to 10 minutes required to complete the necessary measurements. Figure 3 indicates the relation between oxygen consumption and $\mathrm{A}-\mathrm{V}$ difference in this group. The greatest rates of oxygen intake recorded were approximately $250 \mathrm{cc}$. per square meter per minute, and these were achieved only by increasing A-V differences to the region of 9.5 and 10.5 vol. per cent. With the exception of patient No. 13, all cases during exercise exhibited an $\mathrm{A}-\mathrm{V}$ difference which was greater than normal for the rate of oxygen consumption, and in 3 cases this was true even at rest. Of the patients in severe failure, 4 (Nos. 9, 10, 14 and 15) showed a slight decrease of cardiac output during exercise ; 2 (Nos. 11 and 12) showed no substantial change. In 1 case there was no change in oxygen consumption during exercise, and in 1 case (No. 15) there was a slight fall. The decompensated patients, then, were severely limited in their ability to increase oxygen consumption on exercise ; and whatever increase occurred was accomplished by an increase in the A-V oxygen difference. They did not respond to this type of exercise with a rise in cardiac output. The patients who had begun to improve (Nos. 13, 15A and 16), on the other hand, were able to increase their cardiac output during light exercise and thus to prevent a large rise in the $\mathrm{A}-\mathrm{V}$ difference. Patient No. 13 remained within the normal range throughout.

Figure 4 demonstrates the effect of exercise on mean pulmonary arterial pressure and cardiac index. The general picture was that of an elevated pressure at rest and a very substantial further elevation on exercise. The increase of pressure 


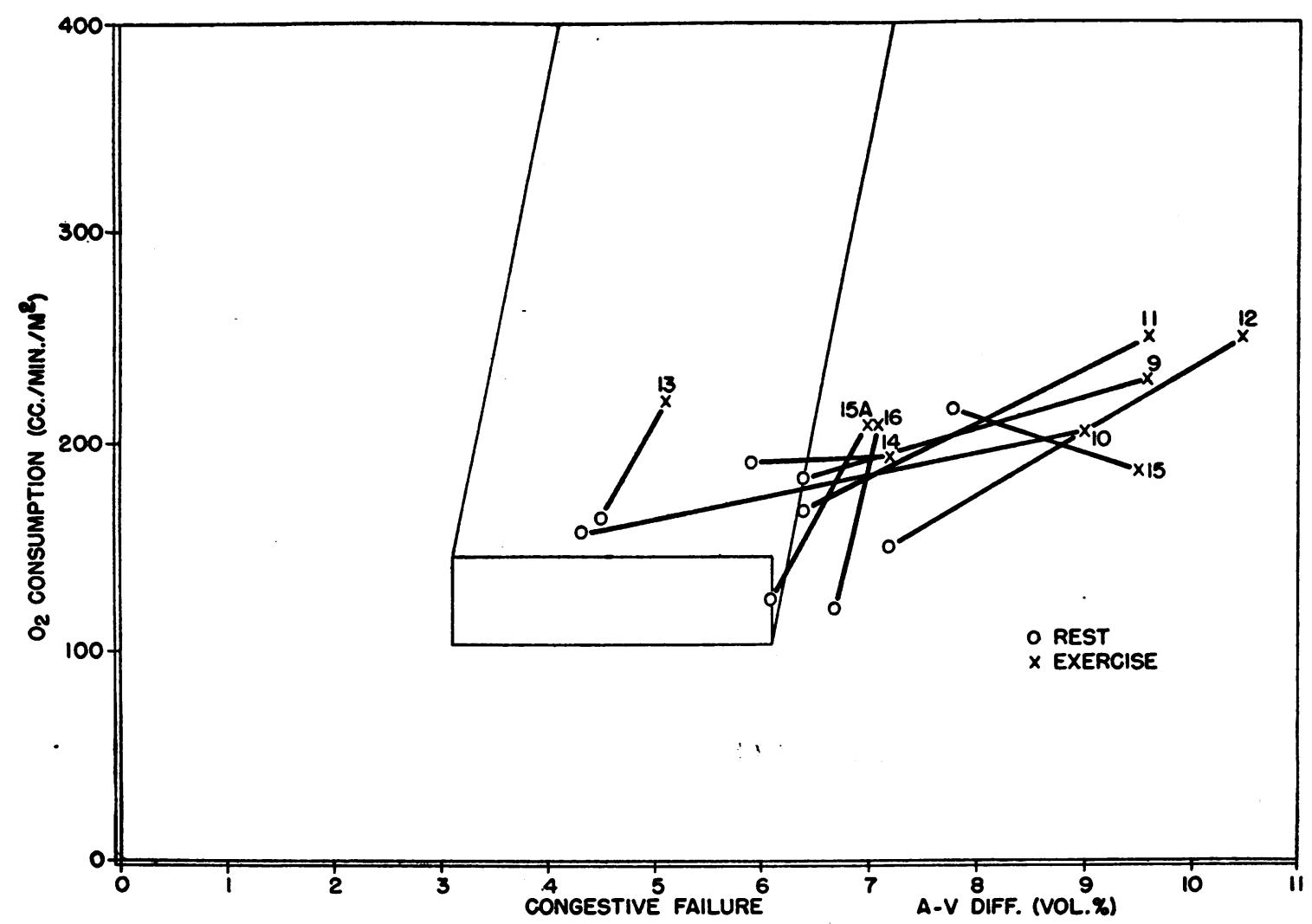

Fig. 3. Effect of Exercise on Oxygen Consumption and Arteriovenous Oxygen Difference in Patients with Congestive Heart Failure

Rectangle and lines indicate normal range as in Figure 1.

on exercise was independent of the direction taken by the cardiac index. In patient No. 15 , the pulmonary pressure was followed at 5-minute intervals during 15 minutes of exercise and was observed to rise gradually to the recorded value.

\section{Mitral stenosis}

Seven patients were studied who had mitral stenosis. One of these (No. 17) also had aortic insufficiency and one (No. 23) had hypertension. In 2 cases (Nos. 18 and 19) only an apical diastolic murmur was present; all other cases had also a systolic murmur at the apex. Patient No. 17 had been asymptomatic. Patients Nos. 18, 19 and 20 had not had frank failure but were short of breath on exertion. Nos. 21 and 22 had had at least 1 episode of failure but were not in frank failure at the time of the study. No. 23 had had repeated failures and was recovering from his latest at the time of study.
Figure 5 relates oxygen consumption to A-V difference in this group. Only 1 patient (No. 23) had an $\mathrm{A}-\mathrm{V}$ difference greater than normal for the rate of oxygen consumption at rest. On exercise 4 patients (Nos. 19, 21, 22 and 23) exceeded the normal range of $\mathrm{A}-\mathrm{V}$ difference. Even in these cases, with the exception of No: 22 , there was a slight rise in cardiac index on exercise, so that the increase in oxygen consumption was not entirely at the expense of the A-V difference.

Figure 6 demonstrates the relation between cardiac index and pulmonary arterial pressure in 4 of these patients. In No. 17 only the ventricular pressure is available. It was not possible to pass the catheter beyond the atrium in Nos. 22 and 23.

In all cases the right ventricular and pulmonary arterial pressures were elevated at rest and became still more elevated on exercise. Patients Nos. 18 and 19 showed very striking increases in pressure with only small increases of cardiac index, 


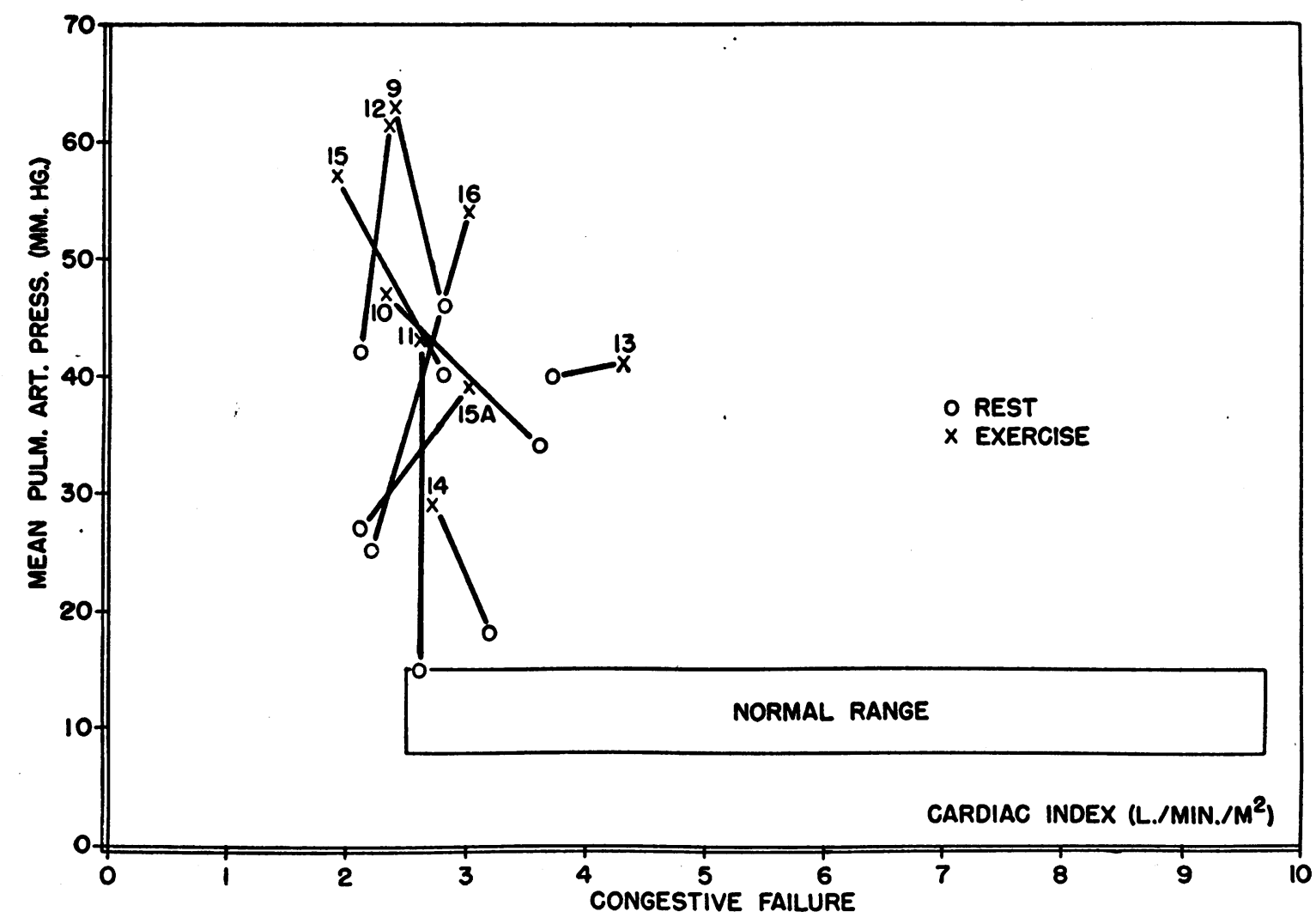

Fig. 4. Effect of Exercise on Mean Pulmonary Arterial Pressure and Cardiac Index in Patients with Congestive Heart Failure

Rectangle incloses range covered by normal subjects during rest and exercise.

thus resembling the behavior of the group with left ventricular failure.

\section{Pulmonary emphysema}

Five patients (Cases 24 to 28 ) were studied who had well advanced pulmonary emphysema. The diagnosis was made by physical examination and $\mathrm{X}$-ray findings. In addition, Cases 24 and 28 had systemic hypertension, but no evidence of cardiac enlargement. Figure 7 indicates the relationship between oxygen consumption and $\mathrm{A}-\mathrm{V}$ difference for the rates of oxygen consumption encountered.

The relationship between mean pulmonary pressure and cardiac index is summarized in Figure 8. With a single exception, the resting pressures exceeded the normal, and on exercise there was a substantial further increase in pressure, well exceeding the normal range in each case. In all cases but No. 28, this increase in pressure was associated with an increase in the rate of blood flow through the lungs. The behavior of No. 28 resembles that of a person with congestive heart failure, but the changes in oxygen consumption and $A-V$ difference during exercise were too small to allow definite conclusions.

\section{DISCUSSION}

\section{Response of cardiac output to exercise}

With exercise there is increased demand of the tissues for oxygen. This demand is met by increasing the amount of oxygen uptake in the lungs either through an increase in cardiac output or through an increase in arteriovenous oxygen difference so that more oxygen is removed by each unit of blood passing through the lungs. During light exercise, normal subjects may use both mechanisms to some extent but the rise in cardiac output predominates and the change in $\mathrm{A}-\mathrm{V}$ oxygen difference is minimized. In persons with an inadequate heart the expected rise in cardiac output cannot occur and the $\mathrm{A}-\mathrm{V}$ difference is greatly increased. 


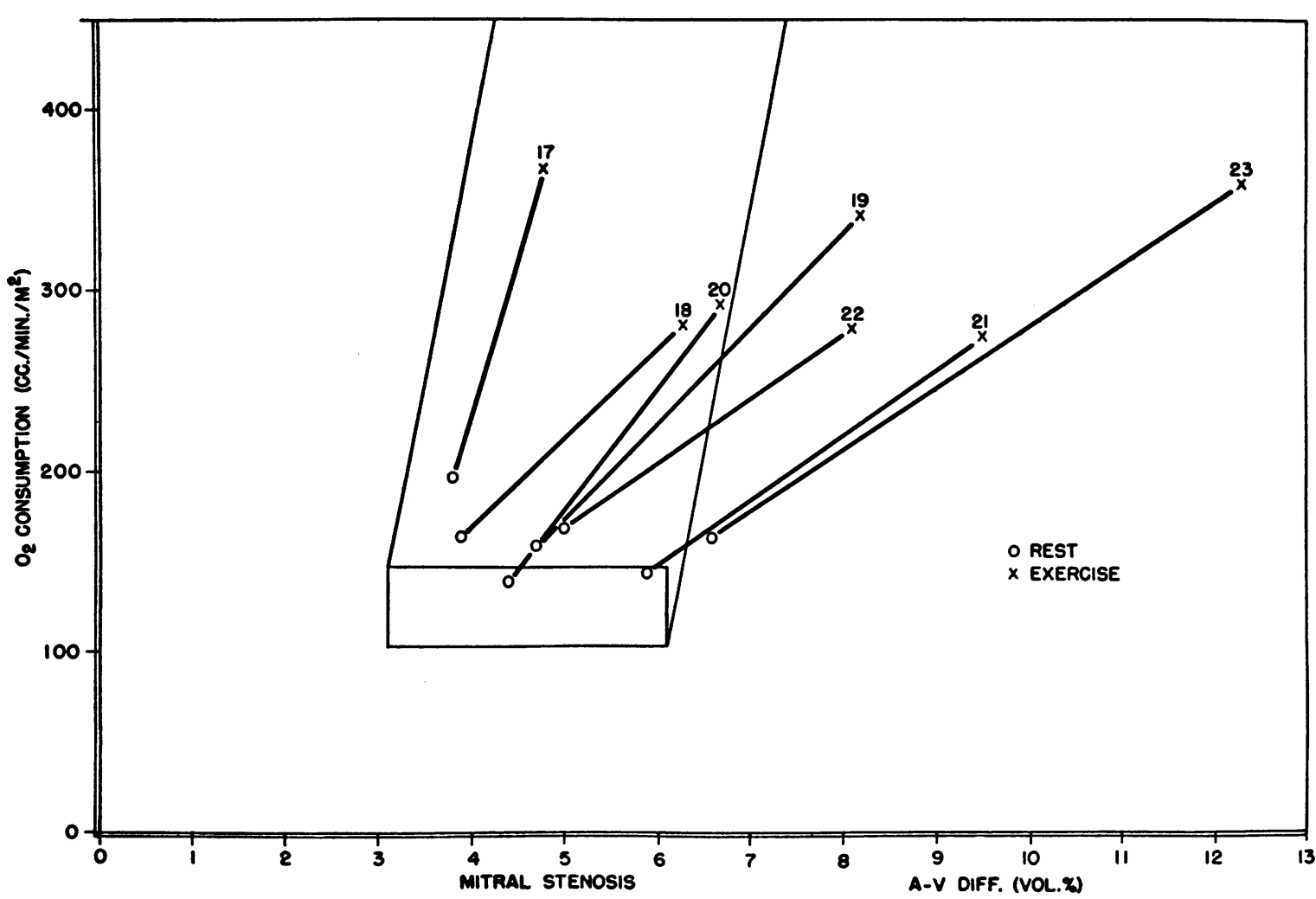

Fig. 5. Effect of Exercise on Oxygen Consumption and Arteriovenous Oxygen Difference in Patients with Mitral Stenosis

Rectangle and lines indicate normal range, as in Figure 1.

All investigators have found that the resting cardiac output is usually decreased in patients with intractable congestive failure. There is some overlap in the values for normal resting subjects and persons with congestive heart failure. This would be expected because the cardiac output is measured under conditions in which the requirements for blood are at a minimum. It would be expected that the difference in cardiac output between normal persons and those with heart failure would be more pronounced if the values for cardiac output in both groups were compared during light exercise. The values for resting cardiac output in normal subjects and in the persons with chronic congestive heart failure reported here do overlap, but the difference between the 2 groups is increased by exercise.

In normal persons during light exercise, there is considerable variation in the cardiac output from one subject to the next. In order to compare the normal response to exercise with the response of the group in congestive failure, it is necessary to choose some criterion to determine whether the cardiac output is adequate for the blood requirements of the body. The level of the arteriovenous oxygen difference is a convenient criterion. If this quantity can be maintained within normal limits while the rate of oxygen consumption is substantially increased, it follows that the response of the cardiac output has been sufficient to maintain a normally high oxygen tension in the tissues. Based on the present results, an upper limit of normal has been chosen for the $\mathrm{A}-\mathrm{V}$ difference during light exercise. The use of this criterion must be somewhat qualified. It is valid, of course, only if the blood oxygen capacity is within the normal range. As the severity of exercise increases, the $\mathrm{A}-\mathrm{V}$ oxygen difference may be expected to increase in a normal person. Because of this, the level of $A-V$ difference chosen as a criterion must be adjusted according to the severity of the exercise. Finally, 


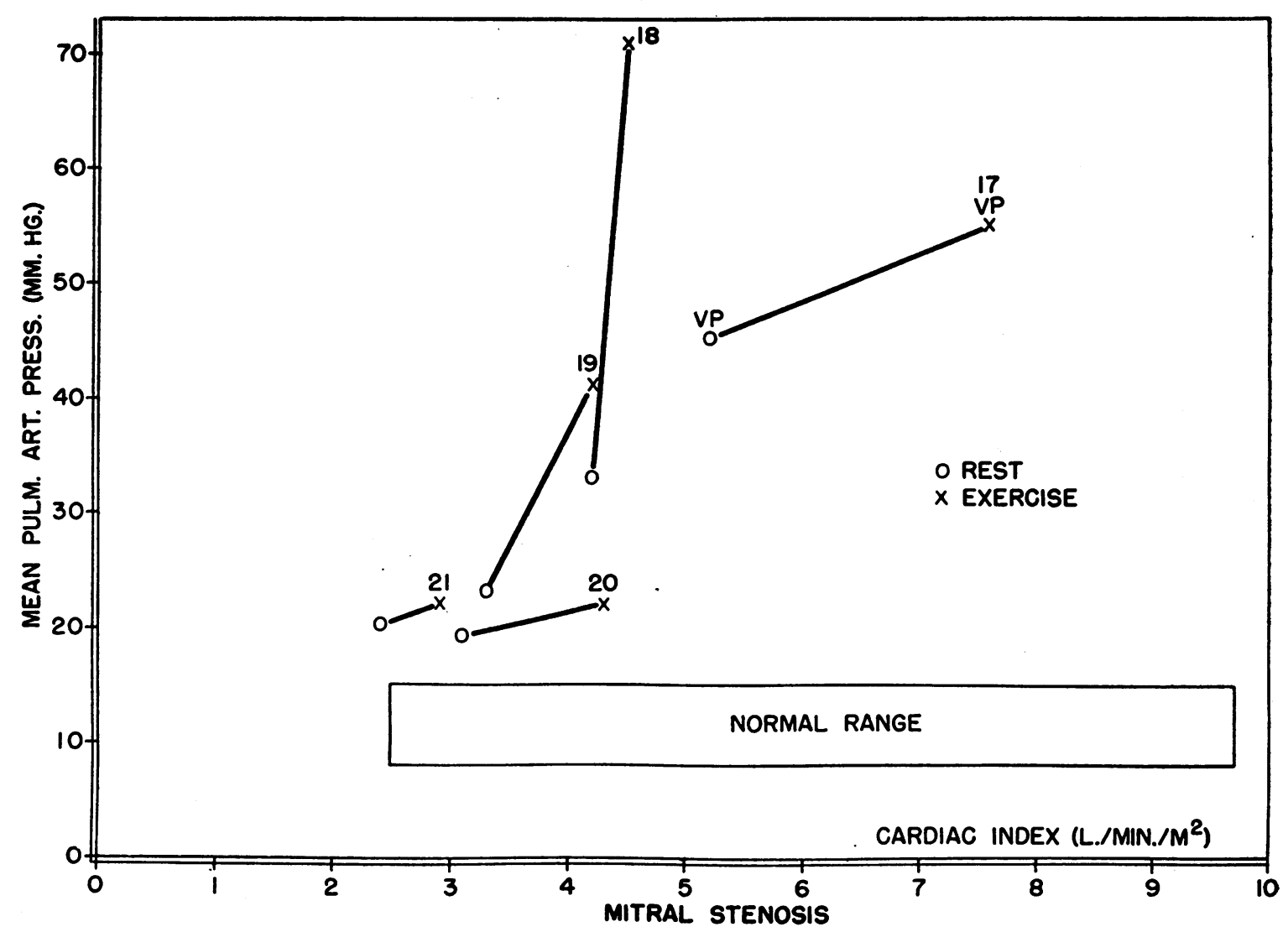

Fig. 6. Effect of Exercise on Mean Pulmonary Arterial Pressure and Cardiac Index in Patients with Mitral Stenosis

Rectangle incloses range covered by normal subjects during rest and exercise. "VP" indicates right ventricular systolic pressure.

the level of $\mathrm{A}-\mathrm{V}$ difference which is used as a criterion for adequacy of the cardiac output cannot be applied to persons who have, in addition to congestive failure, disorders such as thyrotoxicosis and anemia which in themselves affect the A-V difference.

In the present group of normal persons, when the rate of oxygen consumption was increased by exercise to 250 to $400 \mathrm{cc}$. per square meter per minute, the largest $\mathrm{A}-\mathrm{V}$ oxygen difference was 6.8 volumes per cent. This occurred at a rate of oxygen consumption of $285 \mathrm{cc}$. per sq. m. per min. On Figure 1 a line is drawn between this point and that point of the normal basal region which represents the largest $\mathrm{A}-\mathrm{V}$ difference (6.1 vol. per cent) and the lowest rate of oxygen consumption (103 cc. per sq. $\mathrm{m}$. per min.). This line is selected as a boundary which separates the region where cardiac output is probably adequate for the demands made by muscular exercise from the region where output is probably inadequate.

By this criterion the group of patients with congestive failure (Figure 3 ), with a single exception, had an inadequate cardiac response to exercise, and in 6 cases (Nos. 9, 10,11, 12, 14 and 15) the response was grossly inadequate. In 3 cases, as judged by the $\mathrm{A}-\mathrm{V}$ difference, the output was not normally commensurate with the metabolic requirement even at rest. This inability of the heart to respond normally to an increased metabolic requirement is made more striking by the low value of the requirement which was imposed. The largest rate of oxygen consumption attained in this group was $250 \mathrm{cc}$. per sq. m. per min. The 1 patient (No. 13) who remained within the normal range achieved an oxygen consumption of only 220 cc. per sq. m. per min.

During exercise in the group with congestive 


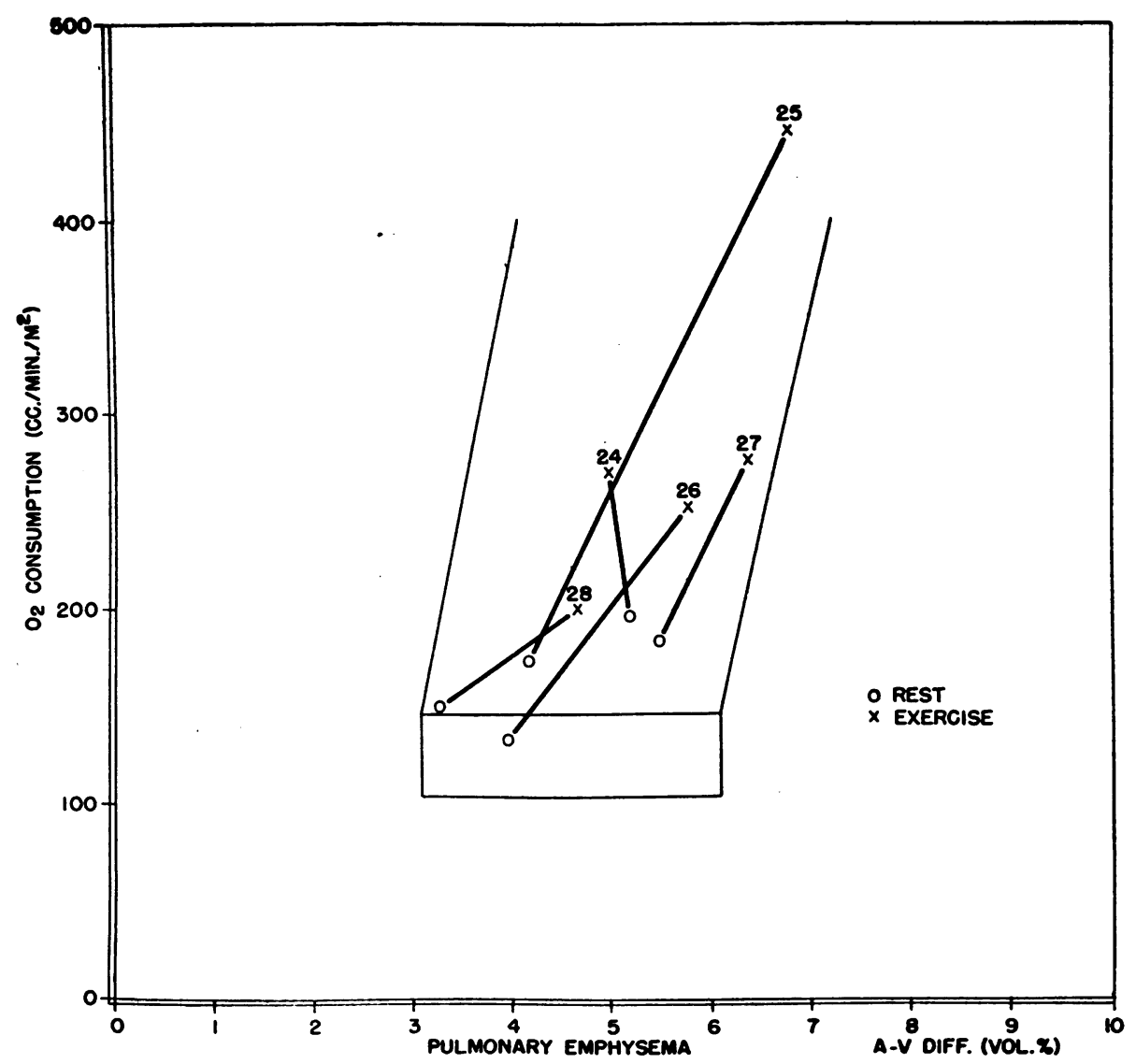

Fig. 7. Effect of Exercise on Oxygen Consumption and Arteriovenous Oxygen Difference in Patients with Pulmonary Emphysema

Rectangle and lines indicate normal range, as in Figure 1.

failure the cardiac output rose slightly above the resting level in 4 cases, remained unchanged in 1 , and fell slightly in 4 cases. In all these cases, the venous blood samples used in determination of the output were taken from the pulmonary artery, where mixing should have been complete. At first sight it seems paradoxical that there should be a fall in cardiac output during the stimulus of exercise. The determination of output, however, was begun only after exercise had been continued for several minutes. It appears probable that the values obtained for output during exercise in the patients with frank failure do not represent a state of equilibrium. It is suggested that the output during steady exercise may rise at first, but then decline even below the resting value as the myocardial reserve is exhausted by the initial sprint.

The significance of the low resting cardiac out- put which occurs in most types of congestive failure is greatly increased by the finding that this is apparently the largest output which the heart can long maintain. Under these circumstances, requirements for extra blood flow to a particular system, such as the muscular structure, can only be met by diverting blood flow from regions in which essential metabolic functions are being conducted. This diversion must result in postponement of many such functions without the possibility of a compensatory increase in blood flow when the extra requirement has passed. It was found by Meakins and Long (3) that following a standard work period the recovery time of cardiac patients, in terms of increased oxygen consumption was greater than that of normal subjects. From this and from the finding of a high blood lactic acid level in congestive failure, they concluded that a decompensated cardiac patient may be in a state 


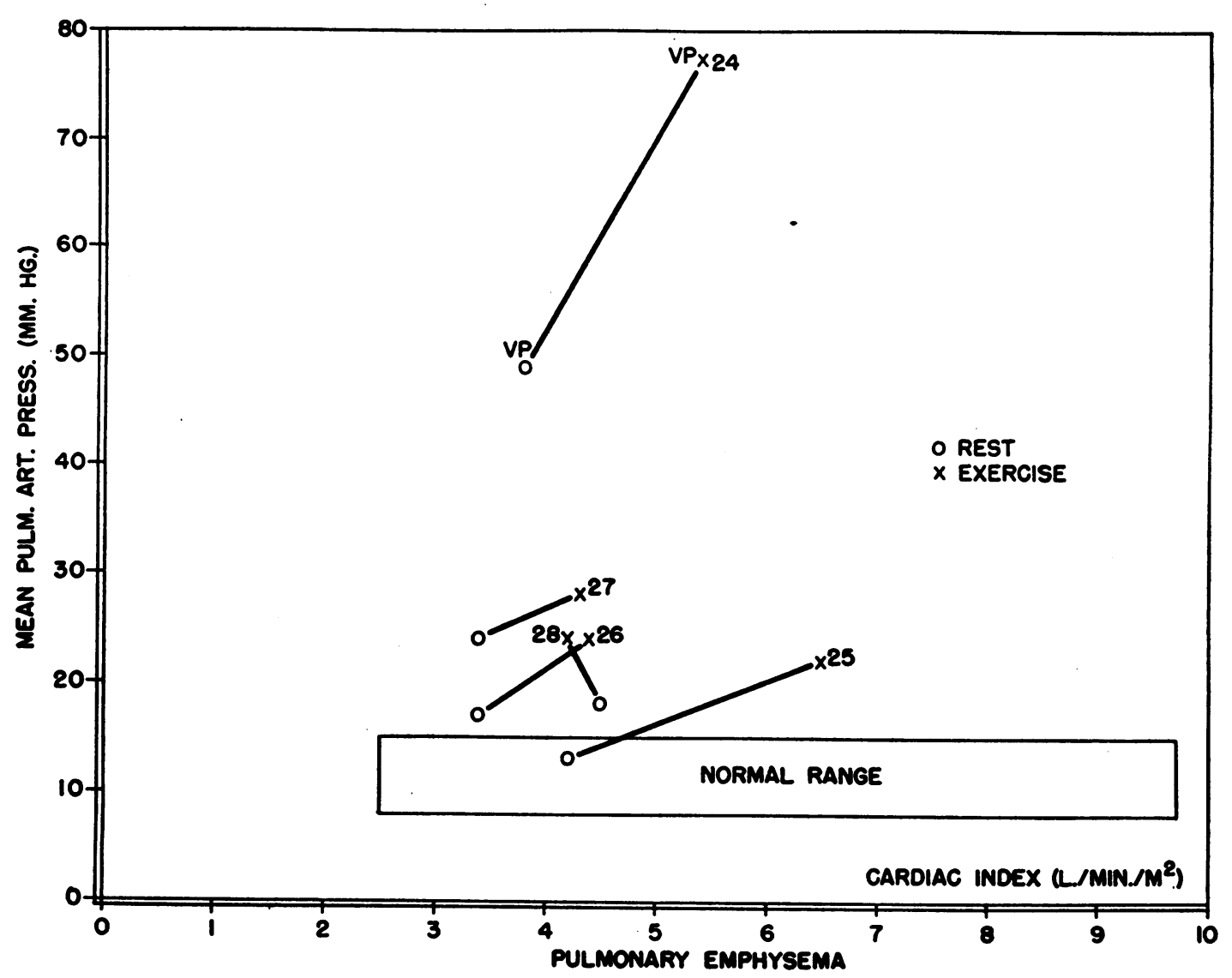

Fig. 8. Effect of Exercise on Mean Pulmon ary Arterial Pressure and Cardiac Index in Patients with Pulmonary Emphysema

Rectangle incloses range covered by normal subjects during rest and exercise. "VP" indicates right ventricular systolic pressure.

of chronic oxygen debt. The present results confirm this conclusion. The presence of a metabolic need to which the heart is not adequately responding is indicated by the frequent finding of an abnormally large $\mathrm{A}-\mathrm{V}$ difference at rest in patients with the ordinary types of congestive heart failure.

In summary, the resting cardiac output in frank congestive failure is the greatest that can be consistently maintained but still may not be great enough to supply the tissues with blood at a rate normally commensurate with their metabolic needs. Any important requirement for additional blood flow cannot be met by increasing the cardiac output but only by diverting blood from one system to another.

Of the patients with mitral stenosis (Figure 5), the $A-V$ difference exceeded the normal range during exercise in 4 instances, indicating a subnormal cardiac response for the amount of work done. Three of these patients (Nos. 21, 22 and 23) had had at least 1 episode of frank congestive failure. The remaining patient (No. 19) had dyspnea on exertion. Of the 3 patients who remained within the normal range, none had ever been frankly decompensated, although No. 18 and No. 20 had dyspnea on exertion. No. 17 had been asymptomatic.

In the group of patients with pulmonary emphysema (Figure 7 ), the A-V difference remained within the normal range for the rates of oxygen consumption achieved, indicating that the cardiac response was adequate for the requirement. In patients with pulmonary emphysema the problem frequently arises as to whether there is co-existent heart failure. In such cases the pres- 
ent method should distinguish those whose cardiac function is adequate within the limits of the work imposed from those whose function is inadequate.

\section{The pulmonary arterial pressure}

The mean pressure in the pulmonary artery depends upon several factors. It is the sum of the left atrial pressure and the pressure gradient between artery and atrium. The gradient, by Poiseuille's law, is directly proportional to the cardiac output and inversely proportional to the "peripheral resistance," a factor which depends primarily upon the number and caliber of small vessels in the pulmonary bed. Finally, in measurement, the mean pulmonary arterial pressure is affected by the mean intrathoracic pressure. The cardiac output was determined in the present study but the relative effects on pulmonary arterial pressure of the left atrial pressure, the condition of the vascular bed (peripheral resistance), and the intrathoracic pressure must be inferred from other evidence.

In normal man, when the cardiac output is increased by exercise up to twice the resting level there is no change, or a small increase in mean pulmonary arterial pressure. As a rule, however, the proportional increase of output is much greater than that of pressure. Accordingly, there must be a compensatory decrease in resistance of the vascular bed, the left atrial pressure, or the mean intrathoracic pressure. Because the absolute value of the pulmonary pressure is quite low, it is difficult to determine the relative importance of these factors. Hamilton (4) has found that the pulmonary bed of the dog can accommodate a large increase in blood flow without a proportional rise in pressure gradient, indicating a decrease in the resistance. In man, Cournand (5) has found that the right ventricular pressure is not significantly increased after pneumonectomy. These observations suggest that the ability of normal man to increase the rate of pulmonary blood flow without a corresponding rise in arterial pressure results from the possibility of opening new vascular channels or of widening those already open.

In the patients with congestive failure, the pulmonary arterial pressure was, on the whole, markedly elevated at rest and showed a striking further increase during exercise. The cardiac output, on the other hand, was low at rest and was not much altered during exercise. In the presence of a low, relatively fixed cardiac output, the high pulmonary pressure and its further elevation on exercise must be referred to a large increase of left atrial pressure, pulmonary resistance, or both. In general, the pressure elevations are of such magnitude as to exclude increases of mean intrathoracic pressure as a significant factor. Certain observations suggest that elevation of the left atrial pressure, or left ventricular diastolic pressure, is responsible in part for the pulmonary hypertension which occurs in congestive heart failure. In persons who die with congestive failure, the pulmonary capillaries are dilated with blood and many more are visible than in the normal lung. This finding demonstrates a low resistance of the capillary bed itself and at the same time suggests a high intracapillary pressure. The experiments of Hamilton (4) have demonstrated that in the dog a very large increase in left atrial pressure results in an equal rise of pulmonary arterial pressure. Some evidence that the high pulmonary arterial pressures of congestive failure are partly transmitted to the capillaries is provided by a patient with systemic hypertension and congestive failure whose case has not been included with the others because the data were incomplete. This patient developed a prolonged attack of acute dyspnea after 6 minutes of light exercise, requiring termination of the experiment. The mean pulmonary arterial pressure at rest had been $42 \mathrm{~mm}$. $\mathrm{Hg}$. The pressure during the attack was not measured, but 5 to $10 \mathrm{cc}$. of blood was driven through the No. 8 catheter into the attached tubing against a gravity head of approximately $90 \mathrm{~mm}$. $\mathrm{Hg}$, resulting in clotting within the catheter. The passage of this quantity of blood through a No. 8 catheter requires a prolonged elevation of pressure. This patient had had spontaneous attacks of paroxysmal dyspnea on the ward. The association of this symptom with acute pulmonary edema is well established, and its occurrence together with a great rise in pulmonary arterial pressure suggests that at least a portion of this pressure was transmitted to the capillaries, resulting in a rapid filtration of fluid through their walls. It is not yet possible to quantitate the role played by constriction of the pulmonary arterioles or the influence on pulmonary pressure of 
stiffening of the lung structure resulting from pulmonary edema.

In the group of patients with mitral stenosis it was anticipated that an increase in the rate of blood flow through the lungs would be attended by a greater than normal increase in pulmonary pressure because of obstruction to outflow from the left atrium. In the 4 cases where it was possible to catheterize the pulmonary artery, the pressures were, in fact, elevated at rest and rose still further when the output was increased by exercise. In 2 of these cases (Nos. 20 and 21) the resting pressures were not greatly elevated, and the increase in blood flow on exercise was proportionately greater than the increase in pressure. The remaining 2 patients (Nos. 18 and 19) demonstrated increases in pulmonary pressure during exercise which were, proportionately, 100 per cent and 50 per cent greater than the respective increases in cardiac output. These pressure changes were of large absolute magnitude. The finding of a pressure rise so disproportionate to the increase in blood flow indicates that some factor in addition to a small, fixed mitral orifice or pulmonary arteriosclerosis must have been operating to produce the pressure increment on exercise. If the resistance of the pulmonary bed and the left ventricular diastolic pressure had remained unchanged, then the rate of flow through the mitral orifice should have been roughly proportional to the mean pulmonary arterial pressure. The large rise in pulmonary pressure without a corresponding increase in cardiac output resembles the behavior of the group with left ventricular failure. The mechanism by which left ventricular failure might occur in mitral stenosis is not immediately apparent. There was no evident cause for cardiac disease other than mitral deformity in these 2 patients, and in neither of them could an apical systolic murmur be heard.

In pulmonary emphysema the existence of pulmonary hypertension has been postulated from the histological picture on the basis that the vascular bed becomes greatly narrowed as the result of destruction of small vascular channels. This narrow bed would then require a higher than normal pressure gradient to maintain a normal rate of flow. Further increments in flow would require greater than normal increments in pressure since the capacity for widening the vascular bed has been largely exhausted. The present results appear to be in accord with this concept. The mean arterial or ventricular systolic pressures were higher than normal at rest except in 1 case. On exercise there was a further rise in pressure which in 4 cases was sharper than normal in proportion to the rise in cardiac output. In the remaining case (No. 28) the pressure rose, while the cardiac output showed a very slight fall. This sequence of events resembles that in congestive heart failure, where the increase in pulmonary arterial pressure on exercise is believed to result largely from a pressure rise in the left atrium. Although patient No. 28 had no signs of congestive failure, she was an elderly woman with a long history of systemic hypertension. It is considered likely that the atypical behavior in this case was the result of an increase in left atrial pressure on exercise. In general, it appears unlikely that large rises in left atrial pressure or in mean intrathoracic pressure could account for the high resting pulmonary arterial pressures in emphysema or for the sharp increase in pulmonary pressure on exercise. The rarity of pulmonary edema during life or of pulmonary vascular congestion at autopsy in these patients argues against the frequent occurrence of a high left atrial pressure. Large changes in the mean intrathoracic pressure should be reflected to some extent in the right atrial pressure. The right atrial pressure (Table I) was not elevated in most of these patients at rest. During exercise it rose, but the rise, except for 1 case, was substantially less than that of the mean pulmonary arterial pressure. For example, in a separate experiment on patient No. 24, it was found that the average right ventricular diastolic pressure increased by $4 \mathrm{~mm}$. $\mathrm{Hg}$ while the ventricular systolic pressure increased by $12 \mathrm{~mm}$. $\mathrm{Hg}$ on passing from rest to exercise. In summary, the available evidence indicates that pulmonary hypertension in emphysema results from narrowing of the vascular bed so that a high pressure gradient is required to force blood through the lung at a normal rate. It should be noted that a normal resting pulmonary arterial pressure in a patient with emphysema does not establish normal function of the pulmonary vascular bed. As illustrated by patient No. 25, pulmonary hypertension may appear only when the rate of blood flow is increased. 


\section{SUMMARY AND CONCLUSIONS}

1. Determinations of cardiac output by the Fick principle and of mean pulmonary arterial pressure were made at rest and during light exercise in 8 persons with a normal cardiovascular system, 8 cases of congestive heart failure due to systemic hypertension or syphilitic aortic regurgitation, 7 cases of mitral stenosis, and 5 cases of pulmonary emphysema.

2. In normal persons during exercise there is an increase in both cardiac output and arteriovenous oxygen difference, but the increase in cardiac output predominates.

3. In persons with congestive heart failure there is little or no increase in the cardiac output during exercise, but there is a large increase in arteriovenous oxygen difference.

4. In frank chronic congestive heart failure the resting cardiac output is the greatest that can be consistently maintained, but even at rest this output may not be great enough to supply the tissues with blood at a rate normally commensurate with their metabolic needs.

5. The cardiac response to exercise may be considered adequate if the arteriovenous oxygen difference can be maintained within normal limits for the rate of oxygen consumption achieved. When the cardiac response is inadequate, the $\mathrm{A}-\mathrm{V}$ difference exceeds the normal limits.

6. The normal pulmonary vascular bed can accommodate a large increase in the rate of blood flow with little or no increase in mean pulmonary arterial pressure.

7. In persons with left ventricular failure, the mean pulmonary arterial pressure is elevated at rest and shows a large further elevation during exercise, with little or no increase in the cardiac output. It is believed that this pressure elevation results in large part from an increase in left ventricular diastolic pressure.

8. In well-marked mitral stenosis the pulmonary arterial pressure is elevated at rest and is further increased during exercise. In certain patients the increase of pulmonary pressure during exercise is greater than can be accounted for on the basis of a fixed obstruction at the mitral orifice.

9. In advanced pulmonary emphysema the pulmonary arterial pressure is usually elevated at rest and becomes still further elevated during exercise. In patients with emphysema who do not have congestive heart failure, pulmonary hypertension is believed to result from destruction of small vessels in the lung with consequent narrowing of the pulmonary vascular bed.

The authors wish to express their appreciation to Dr. Eugene A. Stead, Jr., for his suggestions and assistance in the course of these studies.

\section{BIBLIOGRAPHY}

1. Stead, E. A., Jr., Warren, J. V., Merrill, A. J., and Brannon, E. S., The cardiac output in male subjects as measured by the technique of right atrial catheterization. Normal values with observations on the effect of anxiety and tilting. J. Clin. Invest., 1945, 24, 326.

2. Douglas, C. G., Haldane, J. S., Henderson, Y., and Schneider, E. C., Physiological observations made on Pike's Peak, Colorado, with special reference to adaptation to low barometric pressures. Phil. Trans. Roy. Soc., B, 1913, 203, 185.

3. Meakins, J., and Long, C. N. H., Oxygen consumption, oxygen debt and lactic acid in circulatory failure. J. Clin. Invest., 1927, 4, 273.

4. Hamilton, W. F., Woodbury, R. A., and Vogt, E., Differential pressures in the lesser circulation of the unanesthetized dog. Am. J. Physiol., 1939, $125,130$.

5. Cournand, A., Recent observations on the dynamics of the pulmonary circulation. Bull. New York Acad. Med., 1947, 23, 27. 